\title{
DISKUSSIE OOR DIE MILLENIUM EN DIE HERSTEL
}

\section{VAN ISRAEL}

Ds. J. J. Engelbrecht van Waverley verwys na die artikel in Jaargang 11, Nr. 44 van ds. D. H. Wijnbeek.

Dit verheug my dat daar eindelik gereageer word op my boekie. Behalwe telefoonoproepe en briewe van medechiliaste was daar tot dusver geen kommentaar van anti-chiliastiese kant. Ek het die boekie aan ongeveer 1800 predikante en professore gestuur en vriendelik uitgenooi tot nuwe besinning. Net soos oor die soteriologie, is die Bybel nêrens in teëspraak met homself oor die eskatologie nie. God gee in sy Woord nie vir ons drie verskillende toekomsbeelde om uit te kies nie. God is een en sy profetiese Woord is deurgaans eenstemmig m.b.t. die raad van God oor Israel, die nasies en die kerk.

Omdat die onfeilbare en onveranderbare Woord van God 'n organiese geheel is, ken die Bybel slegs een eskatologiese stelsel, nl. dié van die premillennialisme. Lees bv. slegs Jes. 2 : $1-4$ en glo dat God sê presies wat Hy bedoel en jy moet glo dat die tyd op hierdie aarde afgesluit word met 'n periode van vrede en geregtigheid waar Jerusalem staatkundige en godsdienstige hoofstad is. Jes. 9 : 1-6 sê dat die vrederyk sal bestaan onder die koningsheerskappy van die Messias op die troon van Dawid (Ps. 2 : 6). Dan sal daar ook vrede in die diere-wêreld wees (Jes. 11 en $65: 19-20$ ).

Die toekomstige vrederyk op hierdie aarde is dan ook, naas die verkondiging van die Lam van God wat sou sterwe vir die sonde van die volk, die blye boodskap van die profete vir Israel. Die profesieë berus op die ewige verbond van God met Abraham en later met Dawid. Glo ons hierdie en ander profesieë van harte, dan begin ons uitsien na daardie geseënde tyd en weet ons vanselfsprekend dat die millennium van Openb. 20 daardie tyd moet wees, wanneer Christus op sy messiaanse troon sit en sy opgestane heiliges saam met hom regeer, terwyl die regspraak veral deur die opgestane martelare uit die tyd van die antichris, uitgeoefen sal word. Glo ons dit nie alles nie, dan noem Jesus ons onverstandiges (Luk. $24: 25$ ), glo ons nie soos Paulus die profete in alles nie (Hand. 24 : 14); verag en verontagsaam ons profesieë wat baie vas is (2 Thess. $5: 20 ; 2$ Petr. $1: 19$ ). Wie glo, vind dat die profesieë nie 'n "turksvy" is om weg te beduie nie, maar net so duidelik soos die paasevangelie is om te verstaan. Met vrymoedigheid en vreugde preek ek vir baie jare al oor hierdie heerlike tyd wat nou voor die deur is.

Al die antichiliastiese teorieë verskil teenswoordig hemelsbreed van dié van die grootmeester Augustinus. Geen intelligente teoloog sal sy inlegkunde by Openb. 20 vandag meer napraat nie. Al die teorië kan my nog geen enkele perikoop in die Bybel toon wat daarop dui dat ons nou leef in die "salige ryk waar enkel vrede oor berge en heuwels sweef", wanneer al die nasies Hom dien as onderdaan nie. So sing ons hartlik saam sonder dat die antichilias- 
tiese broeders glo dat daar ooit op hierdie aarde so 'n tyd sal kom.

So gesien, is dit ook vanselfsprekend dat Openb. 20 spreek van 'n letterlike opstanding, die eerste opstanding, die opstanding van die regverdiges, die opstanding uit die dode (d.w.s. van tussen die dode uit) waarna Paulus ook so uitgesien het (Fil. $3: 11$ ). Regtig, die geagte skrywer se poging om die eerste opstanding so te beduie dat dit sien op die saligheid in die hemel terwyl die siele wag op die opstanding by die wederkoms, oortuig hoegenaamd nie. Die feit dat die woord vir ,het gelewe" of "herlewe" drie keer enige twyfel in Openbaring letterlike opstanding uit die dode beteken, een keer in dieselfde teks, maak dit onredelik om dit skielik die vierde keer die saligheid in die hemel van afgestorwe siele te laat beteken.

Ek gee ds. Wi.nbeek gelyk dat dit wat die krone betref oor die bekroning van oorwinnaars gaan. Dit vind in elke geval plaas by die wederkoms, wanneer ook juis die oorwinnaars saam met Christus op sy messiaanse troon sal gaan sit, d.w.s. deelneem aan die regering in die messiaanse ryk op aarde (Openb. $2: 27 ; 3: 21$ ). of beheers die ,siele" nou die nasies? Ek meen dis die bose geeste in die lug, die heirskare van die rondlopende Satan. Of oefen afgestorwe siele nou die regspraak op aarde uit? Dan sou die regters vandag spiritistiese sceances moes bywoon. Maar ek vrees, as hulle dit doen, sal dit demone wees wat die regspraak uitoefen!

Die vergelyking van die toesluiting van Satan in die abussos (afgrond) met die engele van Satan waarvan 2 Petrus $2: 4$ en Judas vs. 6 melding maak, gaan m.i. ook nie op nie, selfs as die blote veronderstelling van ds. Wijnbeek dat hierdie „engele" die Satan en al die bose geeste in die lug wat nou die wêreld beheers insluit, waar sou wees. Hierdie twee tekste is nie parallel met Openb. $20: 2-3$ nie. Eerstens word die engele in die tartarros gewerp terwyl die Satan in die abussos gewerp word. Verder word die enģele in kettings bewaar, maar daar word nie gesê dat bo hulle toegesluit en verseël word nie. Hulle sou dus wel nog beweegruimte hê, soos 'n "hond aan 'n tou", terwyl die Satan volgens Openb. 20 ten enemale soos 'n moordenaar in 'n kerker vasgeketting sit sonder enige moontlikheid om te ontsnap, wat staan nog rond te loop soos 'n leeu om te verslind!

Hierdie twee verwysings na ,engele" is onseker om uit te lê. Geen kommentaar wil hieroor beslis uitsluitsel gee nie. Vir my lyk dit hoogs onwaarskynlik dat dit op Satan en sy bose geeste in die lug slaan. Volgens Openb. 12 verkeer Satan beslis na die hemelvaart van Christus nog in die hemel (oeranos) bokant die aarde. Hy neem daar nog 'n sterk posisie in sodat dit oorlog kos om hom daarvan te verwyder. Daarna word hy oorwin en neergewerp op die aarde en volg daar groot verleiding van "die hele wêreld". Daar is geen sprake dat hy in daardie stadium in die abussos toegesluit sou wees sodat hy nie die nasies kan verlei nie. Dit gebeur eers nadat hy die nasies verlei het, om God en sy Gesalfde te verwerp en die antichris aan te hang. Oor die "millennium" van Augustinus tussen hemelvaart en wederkoms roep die Skrif: „Wee die bewoners van die aarde... want die duiwel het na julle neergedaal". Let wel, hy 
het vanuit die oeranos (hemel) neergedaal en nie vanuit die tartarros opgekom nie! Gedurende hierdie verskriklike antichiliastiese duisendjarige ryk sug die hele skepping in barensnood dat dit tog kan verbygaan en die Satan van die wêreldtoneel verwyder kan word (Rom. $8: 19,22$ ) en die kinders van God geopenbaar kan word.

Ds. W. wil die woordjie „verlei" verander na „beetkry”, sodat dit net beteken dat die Satan gedurende die millennium nie die nasies kan "mobiliseer" nie. Volgens alle woordeboeke en vertalings beteken die Griekse woord egter "verlei" (Cause to wander, cause to err; in die Irre führen", deceive, verführen). Hy wysig die konnotasie van die werkwoord om by sy teorie te pas. Maar ook die denotasie (omvangswydte) van die woord verander hy om dit in te perk om bloot ,mobilisasie" te beteken. Daar is geen enkele grond om dit anders uit te lê as totale verleiding nie: verleiding tot sonde, tot afval van God, tot oorlogvoering. Tereg sê dr. Abraham Kuyper dan ook dat die Satan gedurende die millennium ,die volkere nie meer (sal) kan deer nie” en dat ", hierdie volstrekte niksdoen (sal) strek oor tien eeue" (Van de Voleinding, IV, 34).

Wie het die Islam gemobiliseer teen die Christendom of die kommuniste teen God en sy Christus gedurende hierdie huidige sg. millennium? Gedurende die Bybelse millennium is al sulke verleiding ten enemale uitgesluit. (Terloops, Augustinus sê dat net die gemeente nie verlei word nie!)

Sondes met opgehewe hand sal ook minimaal wees. Christus en sy verheerlikte opgestane heiliges sal meer met 'n ysterstaf regeer, sodat 'n seun wat sondig, honderd jaar oud (Jes. 65) sal sterwe. Die goddelike onderwys sal van Jerusalem uitgaan, sodat die aarde vol sal wees van die kennis van die Here. „Sondeloos" sal die nasies in die vlees egter beslis nie wees nie. Geen chilias het nog ooit so iets beweer nie. Waar kom ds. W. daaraan? Nee, ons idealiseer nie oor die aanstaande vrederyk nie, maar ons glo wel alles wat die profete daaroor sê. Ons jubel saam met die profete in die vooruitsig dat hierdie geseënde messiaanse ryk nou voor die deur is. 